Historic, Archive Document

Do not assume content reflects current scientific knowledge, policies, or practices. 


\section{PRICE LIST AND}

CATALOGUE

TREES

AND THEIR

PEDIGREES

SEASON 1911-12

$\overline{88}$

BALLYGREEN

NURSERIES

HANFORD, WASH.

$\overline{8 \nabla 8}$

NOTE-Pedigree RELIABLY CERTIFIED on Dates of cutting from Parent TREES, also on Date of Delivery to Planters. 
Terms : CasH.-The prices herein quoted are net prices, except on orders amounting to $\$ 25.00$ or more, on which we allow a special discount of $10 \%$ when cash accompanies order. Where one-fourth of the amount is remitted 'with order, the balance to be paid on arrival of stock, we will allow a special discount of $5 \%$. We will prepay freight charges to any railroad station within five hundred miles of Kennewick, Washington, on all orders amounting to $\$ 100.00$ or more, and we guarantee safe arrival of shipments.

Orders of thirty trees of one variety will be sold at the hundred rate. Three hundred trees of one variety will be sold at the thousand rate. Orders of three hundred trees consisting of not less than ten of any one variety will be sold at the thousand rate. On orders less than thirty the each rate will apply.

We make no charge for boxing and packing.

Any claims for error or shortage should be made within five days after shipment is received.

Certificates of inspection are attached to all shipments.

GUARANTEE-Ours means something. When you buy of us you do not buy a "cat in a bag."

We are not infallible and cannot do impossible things, but the Ballygreen system of identification makes the probability of error very remote.

Instructions with invoice. 


\section{APPLES}

SPITZENBURG

Pedigree-Sproat's Hood River Strain. Registered, No. 35. Cuttings certified by C. H. Sproat, Manager Hood River Apple Grower's' Union, Hood River, Oregon.

Mr. C. H. Sproat of Hood River, Oregon, was awarded GRAND STEEPSTAKES PRIZE of $\$ 1,000$; also FIRST PRIZE of $\$ 250$ for the best carload of Spitzenburg at the National Apple Show, Spokane, 1910, and FIRST PRIZE over all exhibitors at the Chicago Apple Show, 1910.

Any praise we might offer in behalf of Hood River Spitzenburg would be superfluous. It is the apples par excellence, and justly famous the world over.

Care, however, should be exercised when planting them, as they do better in districts where they find favorable environment.

ShaPE-Elongated or "sheep nose," desirable for packing and of high commercial value.

CoLon-Bright red, faintly striped with darker red. Firm, crisp and aromatic.

Price for One-Year-Old Trees.

Size, Feet.|Each Lots of 100. Lots of 1000.

\begin{tabular}{l|c|c|c}
4 to 6 & $25 \mathrm{c}$ & $22 \mathrm{c}$ each & $20 \mathrm{c}$ each \\
3 to 4 & $23 \mathrm{c}$ & $20 \mathrm{c}$ each & $18 \mathrm{c}$ each \\
2 to 3 & $18 \mathrm{c}$ & $16 \mathrm{c}$ each & $14 \mathrm{c}$ each
\end{tabular}

\section{WINESAP}

Pedigree-Cy France's W e n a t che e Strain. Registered, No. 45.-Cuttingsacertified by O. G. France, J. S. Greer, and H. W. Reaugh.

Mr. O. G. France won FIRST PRIZE for ten-box, four-tier Winesap at the National Apple Show, Spokane, 1909. SECOND PRIZE for carload of Winesap, National Apple Show, Spokane, 1910.

The entire forty-five acres planted to Winesap, owned by Mr. France at Wenatchee, have all been propagated from the one "mother tree," as Mr. France 
calls it. He noticed that this one tree produced Winesap of a superior quality having the elongated or "sheep-nose" shape with a large uniform size, highly colored; for this reason he selected this tree from which to propagate his Winesap orchard.

It is our opinion that Mr. France has the finest Winesap orchard in the Pacific Northwest, in which district this variety is one of the most dependable and profitable sorts. Good keeping and shipping qualities make it a general favorite. Does well in nearly every district of the Northwest, except in low, damp locations, or in extremely high altitudes.

SHAPE-Ty p i cal elongated Winsap.

CoLor-Rich dark red; crisp and firm with a delightful flavor.

\section{WINESAP}

Pedigree-Wm. Tedford's Wenatchee Strain. Registered, No. 255. Cuttings certified by Wm. Tedford and C. L. Green.

Mr. Tedford won SECOND PRIZE for plate exhibit at Vancouver( B. C.) Apple Show, 1910.

Type, color and quality correspond with Strain No. 45.

Price for One-Year-Old Trees.

Size, Feet.|Each | Lots of 100. Lots of 1000. \begin{tabular}{l|l|l|l}
4 to 6 & $25 \mathrm{c}$ & $22 \mathrm{c}$ each & 20c each \\
3 to 4 & $23 \mathrm{c}$ & $20 \mathrm{c}$ each & 18c each \\
2 to 3 & $18 \mathrm{c}$ & 16c each & $14 \mathrm{c}$ each
\end{tabular}

DELICIOUS

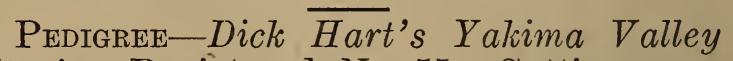
Strain. Registered, No. 55. Cuttings certified by Dick Hart and H. W. Reaugh.

Mr. Hart won FIRST PRIZE for mixed car of Delicious and White Winter Pearmain apples at National Apple Show, Spokane, 1910. He sold his entire crop of Delicious for $\$ 2.371 / 2$ per box as picked from the tree, loose in the box. Our expert selected his trees for propagation while the fruit was on them, six weeks befor the National Apple Show. Mr. Hart grows in his orchard the best colored and 
finest Delicious grown in the Yakima Valley.

Delicious, in our opinion, is the finest DESSERT APPLE grown. It is distinctive in shape with five points on the calyx end of the fruit, has a beautiful red color, is a good keeper and early bearer.

It has a sweet, palatable flavor and a delightful aroma, exceptionally free from acid taste. Seems to prosper throughout the entire Northrest. It is said to be aphis resistant and blossoms late.

\section{DELICIOUS}

Pedigree-Wineland's Wenatchee Strain. Registered, No. 65. Cuttings certified by J. W. Wineland and H. W. Reaugh.

Mr. Wineland of Wenatchee had two hundred and seventy-six trees that are in bearing: He sold the entire crop at $\$ 3.00$ per box. This orchard was selected on account of the striking red color of the fruit and heavy bearing quality of the trees. The Wineland strain is one of the very best and one could not make a mistake in selecting it.

SHape-Elongated or "sheep-nose" with five distinct points on calyx end of fruit.

CoLon-The highest color characteristic of the Delicious.

Price for One-Y ear-Old Trees.

Size, Feet.|Each | Lots of 100. |Lots of 1000.

\begin{tabular}{l|l|l|l}
4 to 6 & $35 c$ & $30 \mathrm{c}$ each & $25 \mathrm{c}$ each \\
3 to 4 & $30 \mathrm{c}$ & $25 \mathrm{c}$ each & $20 \mathrm{c}$ each \\
2 to 3 & $25 \mathrm{c}$ & 20c each & $15 \mathrm{c}$ each
\end{tabular}

ROME BEAUTY

Pedigree- $W m$. Tedford's Wenatchee Strain. Registered, No. 75. Cuttings certified by Wm. Tedford and C. L. Green.

Mr. Tedford won FIRST PRIZE for best plate and FIRST PRIZE for five- and ten-box displays at the Vancouver (B. C.) Apple Show, 1910. FIRST PRIZE for ten-box exhibit at National Apple Show, Spokane, 1909; FIRST PRIZE for fivebox exhibit, National Apple Show, Spokane, 1910. 
Blooms late, an annual bearer, and a general favorite. Keep well, an early bearer and a good commercial variety. Is said to be frost resistant.

SHAPE - Elongated, much longer than the common Rome Beauty.

CoLor-Distinctive Wenatchee Red.

ROME BEAUTY.

Pedigree-Padoshek's Wenatchee Strain. Registered, No. 95. Cuttings certified by Frank F. Padoshek and H. W. Reaugh.

Padoshek Bros. won the FIRST PRIZE for single-box exhibit at the Vancouver (B. C.) Apple Show, 1910, and National Apple Show, Spokane, 1910. (Exhibited through courtesy of Tedford Bros.)

Color and shape similar to Strain No. 75.

ROME BEAUTY

Pedigree-Holt's Pullman Strain. Registered, No. 105. Cuttings certified by J. B. Holt and H. H. Boone. Mr. Holt is producing a Rome Beauty Apple that is distinctive for both color and flavor.

It is the opinion of the horticultural experts at the Pullman Experiment Station, near which Mr. Holt's orchard is situated, that he is producing a Red Rome Beauty just a little different and of superior quality.

Price for One-Year-Old Trees.

Size, Feet.|Each | Lots of 100. Lots of 1000.

\begin{tabular}{ll|l|l}
4 to 6 & $25 \mathrm{c}$ & $22 \mathrm{c}$ each & $20 \mathrm{c}$ each
\end{tabular}

\begin{tabular}{l|l|l|l}
3 to 4 & $23 \mathrm{c}$ & $20 \mathrm{c}$ each & $18 \mathrm{c}$ each
\end{tabular}

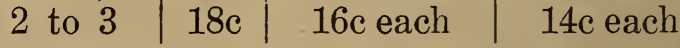

JONATHAN

Pedigrea-Green's Wenatchee Strain. Registered, No. 115. Cuttings certified by C. L. Green and Wm. Tedford. Green Bros. won FIRST PRIZE for best plate of Jonathan over all exhibitors, also SECOND PRIZE for single-box exhibit at Vancouver (B. C.) Apple Show, 1910., and SECOND PRIZE for single-box exhibit at National Apple Show, Spokane, 1910. 
SHAPE-Elongated, making a very desirable commercial apple.

CoLor - A beautiful dark red apple, tender and crisp with a fine flavor.

\section{JONATHAN}

PedigreE-France's Wenatchee Strain. Registered, No. 125. Cuttings certified by O. G. France and J. S. Greer.

Mr. France won FIRST PRIZE for best plate at National Apple Show, Spokane, 1909 and 1910.

Shape and color similar to Strain No.115.

\section{JONATHAN}

Pedigree-Holt's Pullman Strain. Registered, No. 135. Cuttings certified by J. B. Holt and H. H. Boone. Mr. Holt's strain is a high quality of Jonathan.

ShaPE-Long type typical of the Jonathan.

CoLoR-Bright red.

\section{JONATHAN}

Pedigree-Hart's Yakima Valley Strain. Registered, No. 275. Cuttings certified by Dick Hart.

An excellent strain and worthy of propagation. Similar to Strain No. 115.

The Jonathan is a bright red apple, highly flavored, of excellent quality, a splendid cross-pollenizer and a profitable filler. Comes to bearing early. Thrives well in all fruit districts in the Northwest.

Price for One-Year-Old Trees.

Size, Feet.|Each | Lots of 100. Lots of 1000.

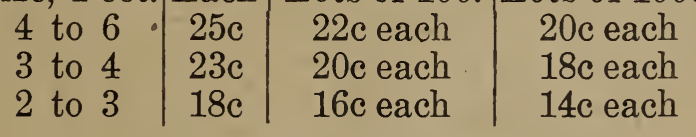

STAYMAN WINESAP

Pedigree-Green's Wenatchee Strain. Registered, No. 145. Cuttings certified by C. L. Green and H. W. Reaugh.

Green Bros won the FIRST PRIZE on single-box exhibit and also SECOND 
PRIZE for plate at Vancouver (B. C.) Apple Show, 1910. Also winner of FIRST PRIZE for mixed four-box exhibit which included Stayman Winesap, National Apple Show, Spokane, 1910.

It thrives better than the old Winesap in high altitudes. In fact, it does well where the old Winesap tends to be small. Flesh, creamy and a very excellent dessert apple.

Shape-Large, slightly conical.

CoLor-A dark red with a somewhat indistinct stripe of lighter red.

Price for One-Year-Old Trees.

\begin{tabular}{c|c|c} 
Size, Feet. & Each. & Lots of 100. \\
4 to 6 & $25 \mathrm{c}$ & $22 \mathrm{c}$ each \\
3 to 4 & $23 \mathrm{c}$ & $20 \mathrm{c}$ each \\
2 to 3 & $18 \mathrm{c}$ & $16 \mathrm{c}$ each
\end{tabular}

KING DAVID

PedigreE-Green's Wenatchee Strain. Registered, No. 155. Cuttings certified by C. L. Green.

Green Bros. won FIRST PRIZE on single-box display at National Apple Show, Spokane, 1910. Also SECOND PRIZE for single-box, and FIRST PRIZE for plate exhibit at Vancouver (B. C.) Apple Show, 1910.

The King David is said to be a remarkably young and heavy bearer, frequently bearing the second year after planting, which makes it desirable for fillers. It is a good keeper. Has been extensively planted in the Wenatchee District.

Shape-Slightly conical and large.

CoLon-A beautiful dark red, seemly a composite of Jonathan and Arkansas Black.

Price for One- $\bar{Y}$ ear-Old Trees.
Size, Feet.
4 to 6
Each.
3 to 4
$35 \mathrm{c}$
$30 \mathrm{c}$
2 to 3
$25 \mathrm{c}$
Lots of 100.
$30 \mathrm{c}$ each
$25 \mathrm{c}$ each
20 c each
NEWTOWN PIPPIN
(Yellow Newtown)
Pedigree-Sproat's Hood River Strain. 
Registered, No. 255. Cuttings certified by C. H. Sproat, Manager Hood River Apple Grower's' Union, Hood River, Oregon.

The Newtown Pippin or Yellow Newtown has contributed in a great measure to make Hood River famous. It is a high quality apple and one of the very best leepers; a good export apple and a general favorite on the English market. Mr. Sproat has a very desirable strain. This apple should be planted in favorable locations, as it tends to be a slow bearer. Flesh, crisp and brittle.

Shape-Conical, tapering to a blunt elongated apple.

CoLor-Bright yellow with a pink blush.

Price for One-Year-Old Trees.

Size, Feet.|Each | Lots of 100. |Lots of 1000.

\begin{tabular}{ll|l|l|l}
4 to 6 & $25 \mathrm{c}$ & $22 \mathrm{c}$ each & $20 \mathrm{c}$ each \\
3 to 4 & $23 \mathrm{c}$ & $20 \mathrm{c}$ each & $18 \mathrm{c}$ each \\
2 to 3 & $18 \mathrm{c}$ & $16 \mathrm{c}$ each & $14 \mathrm{c}$ each
\end{tabular}

WAGENER

Pedigree-Hall's Nob Hill Strain. Registered, No. 235. Cuttings certified by Fred Hall and H. W. Reaugh.

We have selected this strain for the superior quality of fruit grown by $\mathrm{Mr}$. Hall. He has never exhibited, but his Wagener trees produce very fine apples of a beautiful red color.

Shape-True Wagener type oblate.

CoLor-Brilliant red in sun.

\section{WAGENER}

Pedigree-Holt's Pullman Strain. Registered, No. 245. Cuttings certified by J. B. Holt and H. H. Boone.

The best Wagener apple raised in the Pacific Northwest seems to be grown in the Spokane and Palouse River Valleys. We recommend this variety particularly for these districts. It is especially good for fillers in any of the irrigated districts, as it bears very early. The Holt strain is a very select strain. 
Price for One-Year-Old Trees.

Size, Feet.|Each | Lots of 100. |Lots of 1000.

\begin{tabular}{l|l|l|l}
4 to 6 & $25 \mathrm{c}$ & $22 \mathrm{c}$ each & 20c each \\
3 to 4 & $23 \mathrm{c}$ & 20c each & 18c each \\
2 to 3 & $18 \mathrm{c}$ & 16c each & 14c each
\end{tabular}

YELLOW TRANSPARENT

Pedigree-Green's. Wenatchee Strain. Registered, No. 165. Cuttings certified by Green Bros.

Green Bros. won FIRST and SFCOND PRIZES for best plate at both National Apple Show, Spokane, 1910, and Vancouver (B. C.) Apple Show, 1910.

The Yellow Transparent is the best known early apple. Tree very hardy, but thrives best on thin soils.

Shape-Long type.

CoLon-Yellow waxen and transparent.

Price for One-Year-Old Trees.

\begin{tabular}{c|c|c} 
Size, Feet. & Each. & Lots of 100. \\
4 to 6 & $25 \mathrm{c}$ & $22 \mathrm{c}$ each \\
3 to 4 & $23 \mathrm{c}$ & $20 \mathrm{c}$ each \\
2 to 3 & $18 \mathrm{c}$ & $16 \mathrm{c}$ each
\end{tabular}

\section{ARKANSAS BLACK}

Pedigrea-France's Wenatchee Strain. Registered, No. 175. Cuttings certified by O. G. France and J. S. Greer.

Mr. France won SECOND PRIZE for plate exhibit at National Apple Show, Spokane, 1908.

This apple has a sub-acid flavor, coarse, but an excellent keeper and early bearer. Judgment should be exercised in planting, as it thrives best under favorable environments. It is not generally recommended, but is a good pollenizer.

SHAPE-Jarge, cylindrical, sloping slightly to blossom end.

CoLOR-Dark red, almost black.

Price for One-Year-Old Trees.

Size, Feet. Each.

4. to $6 \quad 25 \mathrm{c}$

3 to $4 \quad 23 \mathrm{c}$

\begin{tabular}{l|l|l}
2 to 3 & $18 \mathrm{c}$ & $16 \mathrm{c}$ each
\end{tabular}

Lots of 100.

$22 \mathrm{c}$ each

$20 \mathrm{c}$ each 


\section{MAMMOTH BLACK TWIG}

Pedigree-Hall's Nob Hill Strain. Registered, No. 265. Cuttings certified by Fred Hall. This strain was selected owing to the heavy bearing qualities and unifomity of fruit.

This apple is similar to the Winesap and is called by some the Improved Winesap. Has a pleasant sub-acid flavor.

SHAPE-Large, slightly elongated.

CoLor-Bright red.

Price for One-Year-Old Trees.

\begin{tabular}{c|c|c} 
Size, Feet. & Each. & Lots of 100. \\
4 to 6 & $25 \mathrm{c}$ & $22 \mathrm{c}$ each \\
3 to 4 & $23 \mathrm{c}$ & $20 \mathrm{c}$ each \\
2 to 3 & $18 \mathrm{c}$ & $16 \mathrm{c}$ each
\end{tabular}

WINTER BANANA

Pedigree-Howe's Lehowa Fruit Farm Strain. Registered, No. 185. Cuttings certified by Jno. Beldin, Supt. Lehowa Fruit Farm, Mosier, Ore.

Mr. Howe has a limited number of Winter Banana trees growing in his orchard which have produced a very high quality of fruit. His entire 1909 crop was sold for $\$ 7.50$ per box at New York City. The Winter Banana is strictly a dessert apple. It does well in most of the Northwest districts and particularly in Puget Sound orchards. A fancy market apple, but not recommended for large commercial planting.

SHAPE - Slightly conical, but nearly round.

CoLor-Clear, pale yellow with a delicate pink blush.

Price for One-Year-Old Trees.

\begin{tabular}{c|c|c} 
Size, Feet. & Each. & Lots of 100. \\
4 to 6 & $35 \mathrm{c}$ & $30 \mathrm{c}$ each \\
3 to 4 & $30 \mathrm{c}$ & 25c each \\
2 to 3 & $25 \mathrm{c}$ & $20 \mathrm{c}$ each
\end{tabular}

KING OF TOMPKINS COUNTY

Pedigres-France's Wenatchee Strain. Registered, No. 195.-Cuttings certified by 
O. G. France, J. S. Greer and H. W. Reaugh.

Mr. France won several PRIZES at the Interstate Fair, Spokane. His is a select strain. Especially recommended for the Puget Sound country.

SHape-Slightly tapering to blossom end -large.

CoLOR-Striped, crimson red with slightly lighter stripe of red.

Price for One-Year-Old Trees.

\begin{tabular}{c|c|c} 
Size, Feet. & Each. & Lots of 100. \\
4 to 6 & $25 \mathrm{c}$ & $22 \mathrm{c}$ each \\
3 to 4 & $23 \mathrm{c}$ & $20 \mathrm{c}$ each \\
2 to 3 & $18 \mathrm{c}$ & $16 \mathrm{c}$ each
\end{tabular}

\section{GRAVENSTEIN}

Pedigree-France's Wenatchee Strain. Registered, No. 205. Cuttings certified by O. G. France, J. S. Greer and H. W. Reaugh. Mr. France won FIRST PRIZE at the Interstate Fair, Spokane, 1909.

Tender, crisp and aromatic. One of the highest quality apples. A good grower and regular bearer. Thrives well throughout the entire Northwest.

SHAPE-Large, flat.

CoLon-Streaked and splashed with red over strong yellow.

Price for One- $\bar{Y}$ ear-Old Trees.

\begin{tabular}{c|c|c} 
Size, Feet. & Each. & Lots of 100. \\
4 to 6 & $25 \mathrm{c}$ & $22 \mathrm{c}$ each \\
3 to 4 & $23 \mathrm{c}$ & $20 \mathrm{c}$ each \\
2 to 3 & $18 \mathrm{c}$ & $16 \mathrm{c}$ each
\end{tabular}

Pedigree-Tedford's Wenatchee Strain. Registered, No. 215. Cuttings certified by Tedford Bros.

Tedford Bros. won FIRST and SECOND PRIZES for plate exhibits, National Apple Show, Spokane, 1910.

A beautiful, medium-sized apple, slightly sub-acid flavor, good quality. Yields heavy regular crops. An early bearer. One of the best late summer apples. 
SHAPE-Round and flattish.

Colon-Splashed with red.

Price for One-Year-Old Trees.

Size, Feet. Each.

\begin{tabular}{l|l}
4 to 6 & $25 \mathrm{c}$ \\
3 to 4 & $23 \mathrm{c}$ \\
2 to 3 & $18 \mathrm{c}$ \\
\hline
\end{tabular}

Lots of 100. $22 \mathrm{c}$ each $20 \mathrm{c}$ each $16 \mathrm{c}$ each

\section{GRIMES GOLDEN}

Pedigree-Huxtable's Yakima Strain. Registered, No. 225. Cuttings certified by H. IV. Reaugh.

We have selected this strain from the orchard of W. I. Huxtable, North Yakima, for the superior quality of the fruit grown on the trees.

Shape-Cylindrical, slightly sloping to blossom end.

CoLOR-Golden yellow.

Price for One-Year-Old Trees.

\begin{tabular}{c|c|c} 
Size, Feet. & Each. & Lots of 100. \\
4 to 6 & $25 \mathrm{c}$ & $23 \mathrm{c}$ each \\
3 to 4 & $23 \mathrm{c}$ & $20 \mathrm{c}$ each \\
2 to 3 & $18 \mathrm{c}$ & $16 \mathrm{c}$ each
\end{tabular}

\section{GANO}

Pedigree-Holt's Pullman Strain. Registered, No. 285. Cuttings certified by H. H. Boone and J. B. Holt.

The best of the Ben Davis family; an excellent pollerizer.

Price for One-Year-Old Trees.

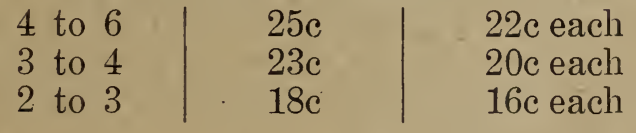




\section{PEARS}

\section{ANJOU}

(Beurre de Anjou)

Pedigree-Thompson's Wapato Strain. Registered, No. 50. Cuttings certified by L. E. Barrick, Manager of Thompson's orchards, and H. W. Reaugh.

One of the very best fall pears. Thrives well in all Northwest fruit districts. It is not a young bearer, but is a desirable and delicious fruit, and one of the best commercial varieties. An excellent strain of this variety is produced by the Thompson Fruit Company, Wapato, Wash.

SHAPE-Large pyriform.

CoLon-Greenish yellow, dashed with dull red and russet.

Price for One-Year-Old Trees. Size, Feet.|Each | Lots of 100. Lots of 1000. 4 to $6 \quad 50 \mathrm{c} \quad 45 \mathrm{c}$ each $\quad 40 \mathrm{c}$ each 3 to $4 \quad 40 \mathrm{c} \quad 35 \mathrm{c}$ each $\quad 30 \mathrm{c}$ each \begin{tabular}{l|l|l|l}
2 to 3 & $30 \mathrm{c}$ & $25 \mathrm{c}$ each & 20c each
\end{tabular}

\section{WINTER NELIS}

Pedigree-Bowes' Yakima Valley Strain. Registered, No. 60. Cuttings certified by W. E. Bowes and H. W. Reaugh.

One of the most delicious pears when properly ripened. Flesh, fine grained and aromatic. A good grower and late keeper. Mr. Bowes grows a very fine strain of Winter Nelis pears. We take pleasure in recommending it.

Shape-Medium pyriform.

CoLon-Yellowish green and russet.

Price for One-Year-Old Trees.

Size, Feet.|Each | Lots of 100. |Lots of 1000.

4 to $6 \quad 50 \mathrm{c} \quad 45 \mathrm{c}$ each $40 \mathrm{c}$ each

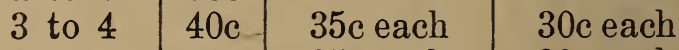

\begin{tabular}{l|l|l|l}
2 to 3 & $30 \mathrm{c}$ & $25 \mathrm{c}$ each & $20 \mathrm{c}$ each
\end{tabular} 


\section{BARTLE'T'T}

Pedigree-Hart's Yukima l'ulle'ls s'train. Registered, No. 70. Cuttings certified by Dick Hart and H. W. Reaugh.

Tree a strong, quick grower and heary bearer; bears young, but resuires calefil cultivation to attain best results. A good pear for preserving and canning. Thrives well in all Northwest districts. It is truly the great commercial pear, and wortliy of more extensive planting on heary soils.

SHAPE-Medium to large pyriform.

COLOR-Yellow with slight blush.

Price for One-Year-Old Trees: Size, Feet.|Each | Lots of 100. Lots of 1000.

\begin{tabular}{l|l|l|l}
4 to 6 & $50 \mathrm{c}$ & $45 \mathrm{c}$ each & 40c each \\
3 to 4 & $40 \mathrm{c}$ & $35 \mathrm{c}$ each & $30 \mathrm{c}$ each \\
2 to 3 & $30 \mathrm{c}$ & 25c each & 20 $\mathrm{c}$ each
\end{tabular}

COMICE

(Doyenne du Comice)

Pedigree-Bear Creek, Rogue Rirer, Strain. Registered, No. 80. Cuttings certified by N. S. Bennett, Medford, Oregon.

The fruit from the Bear Creek orchards captured FIRST PRIZE at Lewis \& Clark Exposition, FIRST PRIZE at A.-Y.-P. Fxposition, FIRST and SECOND PRIZFS at Southern Oregon District Fair, 1909, and in 1907 made a record price for car lots of $\$ 8.50$ per box. The pear par-excellence. It has established a new record for the pear industry. One of the best shippers, longest keepers and of very high quality. Luscions and slightly aromatic.

Shape-Roundish, obtuse-pyriform.

CoLor-Greenish-yellow russet. Blush in sunlight.

Price for One-Year-Old Trees.

Size, Feet. Each.

4 to 6

3 to 4

$65 \mathrm{c}$

$50 \mathrm{c}$

Tots of 100 .

2 to 3

$35 c$

$55 \mathrm{c}$ each 40c each $30 \mathrm{c}$ each 


\section{FLEMISH BEAUTY}

Pedigree-Hall's Nob Hill Strain. Registered, No. 90. Cuttings certified by Fred Hall.

One of the hardiest of the winter pears. Juicy, melting, very sugary and rich.

\section{Shape-Large pyriform.}

.COLon-Pale yellow becoming reddish brown on sunny side.

Price for One-- Year-Old Trees.

\begin{tabular}{c|c|c} 
Size, Feet. & Each. & Lots of 100. \\
4 to 6 & $50 \mathrm{c}$ & $40 \mathrm{c}$ each \\
3 to 4 & $40 \mathrm{c}$ & $30 \mathrm{c}$ each \\
2 to 3 & $30 \mathrm{c}$ & 20c each
\end{tabular}

\section{PEACHES}

Alexander-L a r g e, e a $\mathrm{r} l \mathrm{y}$; greenish white; juicy, clinging.

Foster-Large, early; deep orange red; flesh, yellow, rich and juicy, freestone.

Early Crawford-Large, early; yellow, freestone.

Elberta-Very large, medium early; golden yellow with blush. Flesh rich yellow freestone-the best commercial variety.

Late Crawford-Large, yellow freestone.

SalWaY-Large, late; deep yellow with slight blush; flesh yellow freestone.

Price for One-Year-Old Trees.

Size, Feet.|Each | Lots of 100. |Lots of 1000.

\begin{tabular}{|c|c|c|c|}
\hline to 6 & $25 c$ & $20 \mathrm{c}$ each & $18 \mathrm{c}$ each \\
\hline to 4 & $20 c$ & $18 \mathrm{c} \mathrm{each}$ & $16 \mathrm{c}$ eac \\
\hline 2 to 3 & 18 & $16 \mathrm{c} \mathrm{each}$ & $14 \mathrm{c} \mathrm{eac}$ \\
\hline
\end{tabular}

APRICOT

Moorpark-Largest; orange, with red cheek, fine and juicy.

Early Golden-Small, pale yellow.

Hemshirk-Large; orange, with red cheek; juicy, sub-acid.

RoyaL-Large; yellow, with orange cheek; flesh pale yellow.

Tilton-Large, highly flavored, melting.

Price for One-Year-Old Trees.

Size, Feet. Each.

4 to 6

$40 \mathrm{c}$

3 to 4

$35 \mathrm{c}$

$35 \mathrm{c}$ each

$30 \mathrm{c}$ each 


\section{NECTARINE}

EARLY VIOLET-Medium; yellowish green with purplish cheek; flesh pale yellow.

Bostow-Very large; deep yellow with bright blush; flesh yellow.

Price-Each, 30c.

\section{QUINCE}

Orange-Large, bright golden yellow.

Champion-Very large, excellent flavor. Pineapple-Exquisite and delicate flavor. Price-Each, 50c.

\section{CRAB}

Transcendent-Medium; yellow, partly colored with red.

Red Siberian-Small; grows in clusters. Whitney No. 20-Large; glossy green, splashed with carmine; flesh firm and juicy.

Price-Each, 35c.

\section{PLUM}

ABundance-Large, yellowish green with red cheek.

PeACH-Largest; red, fine dessert plum. Burbank-Very large; yellowish with red cheek; flesh yellow.

YELLOw EGG-Very large; yellow; eggshaped, excellent for cooking.

Blue Damson-Small; oval; skin dark purple; much used for preserves.

Price-Each, 35c.

\section{PRUNES}

French or Petite-Medium; reddish purple; sugary, excellent for preserves.

Srlver-Large; skin pale yellow; sweet.

Sugar-Large; dark purple; yellow flesh, sugary, tender.

ItaLIan-Medium to large; dark purple; sweet and delicious.

Tragedy-Medium; dark purple; flesh yellowish green, rich and sweet.

Price-Each, 35c. 


\section{CHERRY}

Sweet Varieties.

Royal Ann-Large; pale yellow with dark cheek; one of the best dessert cherries.

Black Republican-Large; dark, rich and solid.

LAMBERT-Large; dark purplish red; flesh firm, rich and juicy.

Bing-Large; almost black; very fine; an excellent market variety.

\section{Sour Cherries.}

MaY Duke-Medium; dark red, rich and juicy.

LATE DUKe-Large; dark red, sub-acid.

Early Richmond-Medium; bright red; rich acid flavor.

English Morello-Medium; black and red; rich and juicy.

\section{Price for One-Year-Old Trees.}

\begin{tabular}{c|c|c} 
Size, Feet. & Each. & Lots of 100. \\
4 to 6 & $50 \mathrm{c}$ & $35 \mathrm{c}$ each \\
3 to 4 & $40 \mathrm{c}$ & $30 \mathrm{c}$ each
\end{tabular}

\section{GRAPES}

Our European and American varieties of Grapes, were selected from the very best bearing vines and are first-class, wellrooted stock.

Flame Tokay

Black Hamburg

Empress

Black Ferrara

Malaga

Muscat of Alexandria

Thompson's Seedless

Sweetwater

Black Malvoịse

\section{Rammonia}

American Varieties.

Moore's Early

Worden

Concord

Brighton

Niagara

Cambell's Early

Price for One-Year-Old, Well-Rooted Stock.

Each. Lots of 100 . Lots of 1000.

$25 \mathrm{c} \quad 15 \mathrm{c}$ each $10 \mathrm{c}$ each

Cambell's Early, 10c extra. 


\section{BLACK BERRIES}

Wilson

Erie

Merseau
Himalaya Giant

Snyder

Evergreen

Price for One-Year-Old, Well-Rooted Stock

Each. Lots of 100. Lots of 1000. $20 \mathrm{c} \quad 12 \mathrm{c}$ each $10 \mathrm{c}$ each

Himalaya Giant, 10c extra.

\section{RASPBERRIES}

RED

Cuthbert

Antwerp

Loudan
BLACKCAP

Cumberland

Gregg

Price for One-Year-Old, Well-Rooted Stock.

Each. Lots of 100. Lots of 1000.

$20 \mathrm{c} \quad 10 \mathrm{c}$ each $\quad 8 \mathrm{c}$ each

\section{DEWBERRIES}

Lucretia

Premo

Price for One-Year-Old, Well-Rooted Stock.

Each. Lots of 100. Lots of 1000.

$25 \mathrm{c} \quad 15 \mathrm{c}$ each $12 \mathrm{c}$ each

$$
\text { CURRANT }
$$

Cherry

$$
\text { Fay's Prolific }
$$

\section{Black Champion}

Price for One-Year-Old, Well-Rooted Stock.

Each.

$20 \mathrm{c}$ Lots of 100.

$12 \mathrm{c}$ each

\section{GOOSEBERRIES}

Oregon Champion

Houghton

Price for One-Year-Old, Well-Rooted Stock.

Each.

$25 \mathrm{c}$
Lots of 100 .

$12 \mathrm{c}$ each

\section{VINES}

Ampelopsis $\$ .60$

Honeysuckle .60

Clematis

Wisteria 


\section{Ballygreen Nurseries}

\section{Hanford, Wash.}

Prices on Pedigree Apple Trees. All varieties.

$\begin{array}{lccc} & 30 & 300 & 2000 \\ & \text { to } & \text { to } & \text { to } \\ & 100 & 1000 & 2500 \\ \quad \text { Size } & \text { each } & \text { each } & \text { each } \\ 4 \text { feet up } & 20 \mathrm{c} & 18 \mathrm{c} & 16 \mathrm{c} \\ 3 \text { to } 4 \text { feet } & 18 \mathrm{c} & 16 \mathrm{c} & 14 \mathrm{c} \\ 2 \text { to } 3 \text { feet, heavy } & 12 \mathrm{c} & 10 \mathrm{c} & 8 \mathrm{c}\end{array}$

This list cancels all previous quotations on pedigree apple trees.

October, 1911. 




\section{HEDGE}

Per Doz.

Barberry Purple, 15 to 18 inches. $\$ 2.00$ Box, 10 to 12 inches 5.00

Privet California, 18 to 24 inches

- DECIDUOUS ORNAMENTALS

American Elm, 6 to 8 feet. $\$ .60$

American Linden, 6 to 8 feet. .60

Black Locust, 6 to 8 feet. .50

Norway Maple, 6 to 8 feet. .60

Sugar Maple, 6 to 8 feet. .60

Sycamore Maple, 6 to 8 feet.

Soft Maple, 6 to 8 feet.

Carolina Poplar, 6 to 8 feet. .50

Almond .40

American Black Walnut. .35

Franquette Walnut

Mayette Walnut

.50

.50

.50

\section{- SHRUBS}

Althea, 2 to 3 feet. $\$ .75$

Calycanthus .60

Deutzias .75

Forsythia, 2 to 3 feet. .60

Lilac, 2 to 3 feet .60

Spirea, 3 to 4 feet .75

Snowball, 3 to 4 feet. .75

Weigelas, 2 to 3 feet.

Roses, 2 years, per doz .75 Hydrangea, 2 to 3 feet. 4.50 .75 